\title{
Mutter Tutein - Den »kloge kone« i Affenraa - og hendes tid
}

Af Johannes Brix

I sidste del af forrige århundrede og første del af dette århundrede virkede Helene Christine Tutein som klog kone i Åbenrå.

De lægelige landvindinger var endnu kun sparsomme og overtroen stor. Dette kunne være baggrunden for hendes virke. I dag er folk oplyste, det lægevidenskabelige stade højt, og adgangen til lægehjælp gratis. Det kan derfor undre, at ca. 1/3 af alle patienter, der henvender sig til deres praktiserende læge i dag, forinden har søgt at selvbehandle sig. Imidlertid er denne selvbehandling i langt de fleste tilfælde relevant. ${ }^{1}$

Man må formode, at syge mennesker for 150-200 år siden i overvejende grad var henvist til selvbehandling, og at de kun i yderste nødstilfælde søgte læge. For 200 år siden og endnu længere tilbage i tiden må man antage, at befolkningen slet ikke har søgt læge ved almindelige sygdomme. Én af årsagerne var, at der kun fandtes meget få læger, og de, der fandtes, var hovedsagelig bosiddende i de større bysamfund. Størstedelen af de læger, der praktiserede uden for København, var offentlig ansatte (= embedslæger) og oppebar kun en ringe fast løn. De var derfor henvist til at supplere indtægterne med virksomhed som praktiserende læge. Dette forhold sammenholdt med de ofte store afstande, patienterne måtte tilbagelægge for at komme til læge, har sikkert været medvirkende til, at lægesøgningen ikke har været stor. Det var derfor nærliggende, at befolkningen $i$ overvejende grad søgte hjælp hos »kloge koner og mænd, omkringrejsende sygdomshelbredere, charlataner, kvaksalvere og andet godtfolk «.

Begrebet kvaksalveri omtales i de første medicinalforordninger fra $1619^{2}$ og $1672 .^{3}$ En kvaksalver er en person, der ikke har autorisation som læge, og som tager syge mennesker i kur. Dette har været og er stadig tilladt. Det er derimod ikke tilladt at betegne sig som læge, uden at man har en autorisation som sådan. Det har altid været forbudt at udsætte syge for påviselige farer, og derudover findes der yderligere en del begrænsninger for kvaksalveres udfoldelsesmuligheder.

Den første læge i hertugdømmet Slesvig nedsatte sig i Flensborg 
$1603,{ }^{4}$ og der var først efter datidens forhold acceptabel lægedækning $i$ hertugdømmet efter 1850 . Vi kender $i$ dag ikke tilstrækkelig til tidligere tiders sygdomsforekomst, idet medicinalstatistik først blev systematiseret efter etableringen af det Slesvig-Holstenske Sanitetskollegium i Kiel 1804. ${ }^{5}$

Der er flere gange i det sønderjyske område gjort tilløb til en sygekasseordning for at begrænse de udgifter, der kunne være forbundet med at blive syg og lade sig behandle af en læge.

Hermann Grube (1637-1698) synes at være den første, der oprettede en form for sygeforsikring. Grube var fysikus i Haderslev, og ordningen omfattede så vidt vides kun de i forvejen velsituerede embedsmænd i Haderslev amt. ${ }^{6}$ Senere har bl.a. fysikus i Sønderborg fysikatsdistrikt Johan Heinrich Herman Julius Schmiegelow (1819-1912) søgt at få etableret en sygeforsikring, men da han første gang prøvede i 1865, var det nok for fremsynet, - ordningen blev ingen succes. ${ }^{7}$

Der har virket kirurger og barberer i Åbenrå i umindelige tider. Den første, vi kender navnet på, var Jens Balbirer (?), der har virket omkring 1608. Den sidste forlod Åbenrå $1809 .{ }^{8}$ Åbenrå fik sin første læge i 1742. Fra 1757 har der tillige boet en fysikus (= embedslæge) i byen. ${ }^{9}$

Omkring år 1900 havde Åbenrå med sine knap 6000 indbyggere foruden embedslægen (Kreisarzt på tysk) fem praktiserende læger. ${ }^{10}$ Mange af de læger, der virkede på fru Tuteins tid, er der stadig erindring om, $\mathrm{i}$ hvert tilfælde deres navne. Således nedsatte dr. Wiemer sig $\mathrm{i}$ Åbenrå 1885. Han praktiserede indtil sin død i 1921 . I 1890 nedsatte dr. Butzbach sig i byen. Han praktiserede til kort før sin død i 1947. I tilslutning til en konflikt med sygekasserne i 1890 nedsatte to nye læger sig, det var dr. Dibbern og dr. Huss, der kom i 1891. Dibbern døde i 1932 og Huss i 1946. Da der i 1893 nedsatte sig yderligere en læge, dr. Schmidt, blev det de allerede etablerede for meget. Om den nye læge skal dr. Dibbern og dr. Huss have sagt på et lægemøde: »Der Kollege wird nicht besucht, und im Verkehr geschnitten. “11

Når man kaster et blik på hospitalsforholdene i Åbenrå, så var disse i slutningen af 1800 tallet kummerlige. Således rådede byen i adskillige år kun over det lille sygehus i Persillegade 6 med plads til ca. 14 patienter. Åbenrå kreds overtog 1888 det nedlagte militære lazaret i Nygade 55 og etablerede et civilt sygehus der. Forholdene var imidlertid ikke tidssvarende, og da Åbenrå kreds påbegyndte byggeriet af det nuværende sygehus i 1891, ønskede Åbenrå by også at kunne benytte dette. Der var ingen fastansat læge, men en tilsynsførende, nemlig dr. Wiemer. Han havde stillingen indtil 1913. Samtlige læger i Åbenrå 
fysikatsdistrikt kunne indlægge deres patienter og selv behandle disse på sygehuset. Dette forhold ændrede sig, da Åbenrå amt og by ansatte en kirurgisk overlæge ved sygehuset i 1913. Det var dr.med. Max Jansen (1884-1938). Sygeplejen blev varetaget af diakonisser udstationeret fra Diakonissenanstalt i Flensborg. ${ }^{12}$

Åbenrå havde ved århundredskiftet to apoteker. På Storetorv Løveapoteket, som var oprettet i 1709 og Svaneapoteket i Ramsherred, etableret i 1851 . I 1887 etablerede den første dentist (= tandlæge) sig i byen. Det var Herman Michael Kopp (1865-1917), der efter afsluttet læretid i Berlin nedsatte sig i sin fødeby med »atelier« i Rådhusgade. Huset har måttet vige for moderne byggeri.

Tidligere tiders lægebehandlingsmetode er os ganske godt bekendt. Derimod er vor viden om f.eks. kirurger og barberer væsentlig mindre, og der foreligger næsten ingen skriftlige beretninger om kloge folks virke. Der er flere årsager hertil; men én af de væsentligste er nok, at mange kloge koner og mænd søgte at ledsage deres behandlingsindsats med en mystificerende aura. Det må antages, at det netop er det mystiske, der har været det væsentlige i behandlingsprincippet. Dette underbygges også af det forhold, at det var en almen udbredt tanke, at sygdomsårsager var imaginære, uforståelige, hvorfor behandling med rationelle midler ville slå fejl.

I det sidste halvt hundrede år har denne sygdomsopfattelse været på retur, og der er kommet mere åbenhed omkring »kloge folk«s behandlingsprincipper. Det har derfor været mulig for mig ved samtaler med ældre mennesker at fă et vist indblik i disses aktiviteter.

En af de mest kendte »kloge koner«, der har virket i Åbenrå, har nok været fru Tutein. Mange ældre Åbenrå-borgere har hende stadig i erindring; men den konkrete viden, adskillige mennesker havde om hende og hendes aktiviteter som »klog kone«, var så modstridende, at det kunne være af interesse at sammensætte den viden, man kunne indsamle om hendes virke. Efterfølgende fremstilling er baseret på trykte såvel som utrykte kilder, en stor del af min viden om hendes behandlingsprincipper er baseret på mundtlige overleveringer.

Navnet Tutein kunne forlede en til at tro, at fru Tutein var af fransk afstamning, det var imidlertid ikke tilfældet. Hun blev født i Åbenrå den 8. december 1835 som datter af snedkermester Johan Andreas Bernhard Petersen (1800-1884) og dennes hustru Cathrine Elisabeth, født Eklon. Ved dåben fik hun navnet Helene Christine. Om hendes barndom og ungdom ved man meget lidt; men hun har formentlig 
tilbragt det meste af sin tid i forældrenes hus Nybro 8 i Åbenrå. I 1862 giftede hun sig med skibskaptajn Fritz Peter Tutein. Han var født i København den 14. maj 1831 som søn af skibskaptajn Johan Dietrich Cornelius Tutein og dennes hustru Helene Johanne, født Boysen fra Sønderballe. Familienavnet stammer fra hugenotter, der var indvandret via Tyskland fra Frankrig. ${ }^{13}$

Om Fritz Peter Tutein vides meget lidt. Han skal have været kaptajn på flere skibe hjemmehørende i Åbenrå. Imidlertid anfører Schlaikier ${ }^{14}$ og Holm-Petersen ${ }^{15}$ kun navnet Tutein som skibsfører på nogle skibe

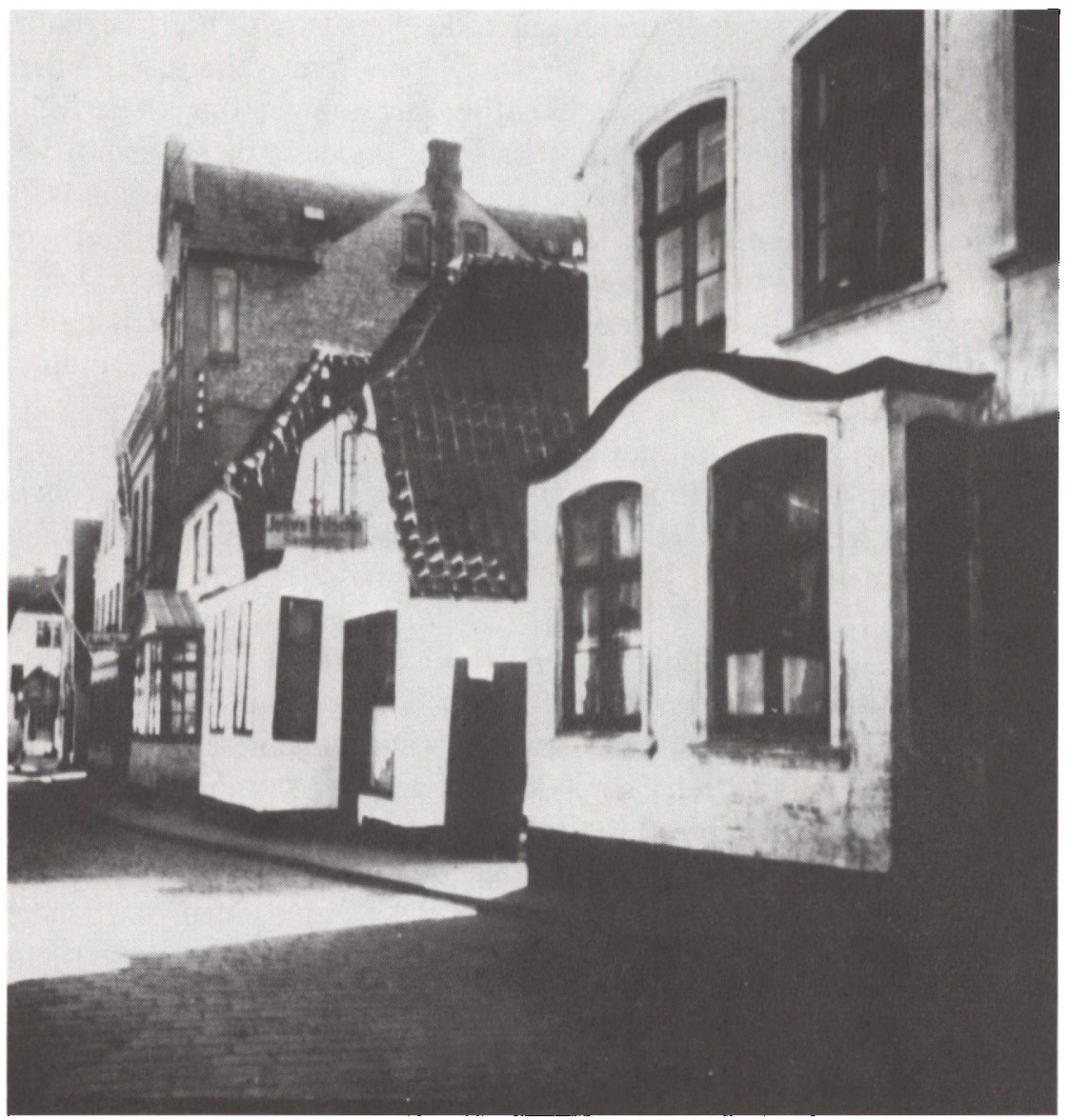

Fra hojre mod venstre ses husene Nybro nr. 2, 6 og 8 i Abenrd. Fru Tutein boede i nr. 8 pd 1. sal. Det er pả billedet det sidste hus med hvid facade og karnap. (Foto formentlig fra 1920'rne. Historisk Samfund for Sonderjylland) 
hjemmehørende i Åbenrå. Det vides dog, at der har været flere skibsførere med familienavnet Tutein.

Helene Christine Tutein fødte den 13. februar 1863 en datter, der døde kun 7 uger senere. Fritz Peter Tutein døde i året 1875.

Fru Tutein må som ganske ung have haft en eller anden form for tilknytning til sygeplejen, idet det nævnes i en skrivelse fra Vaterländischer Frauenverein til landråden i Åbenrå, at hun havde deltaget i krigen 1864 på slesvig-holstenernes side. Hun skal have været ansat på et lazaret, men da der ikke har været ansat kvindeligt personale på de militære lazaretter, har hun formentlig arbejdet på et civilt. ${ }^{16}$

I den fransk-tyske krig 1870-1871 deltog fru Tutein på preussisk side som sygeplejerske. Denne gang har hun muligvis været tjenestegørende på de store, mere tilbagetrukne lazaretter, hvor der har været ansat kvindelige sygeplejersker. ${ }^{17} \mathrm{Da}$ hun allerede i 1867 var medlem af Vaterländischer Frauenverein, kan dette være forklaringen på, at hun har deltaget $\mathrm{i}$ krigen som medhjælp på et lazaret.

Vaterländischer Frauenverein var en forening, hvor hovedsagelig kvinder fra det bedre tyske borgerskab var medlemmer. Den var grundlagt i 1867 og havde efterhånden afdelinger i samtlige større byer. Et af foreningens hovedformål var $i$ fredstid at uddanne kvinder til at kunne påtage sig plejeopgaven af sårede soldater i krigssituationer. I fredstid bestod hovedaktiviteterne $i$ at udbrede kendskab til sygepleje og yde hjælp i sociale nødsituationer. I Åbenrå blev der etableret en lokal forening i 1890, og den havde ved århundredskiftet mellem 150-200 medlemmer. Fru Tutein var fra starten i 1890 til 1911 medlem af bestyrelsen. Hun ledede således en kreds af fattige kvinder, der ved syning, strikning og anden form for håndarbejde tjente lidt ekstra, idet medlemmer af foreningen og en del af byens handlende stillede materialer gratis til rådighed. Dette arbejde forestod hun endnu $i$ 1911 som 76 årig. Det skal nævnes at der eksisterede endnu en tysk kvindeforening. Foreningens navn var Frauenwohl, og den havde som sit hovedformål sociale aktiviteter, især at yde hjælp til kvinder i nød som f.eks. enlige mødre, mødre med mange børn og mødre med syge børn. Frauenwohl opnåede aldrig tilnærmelsesvis samme antal medlemmer som Vaterländischer Frauenverein. ${ }^{18,} 19$

Som påskønnelse for fru Tuteins humanitære indsats i krigen 1870-71 fik hun fra officiel tysk side som eneste kvinde i SlesvigHolsten i 1872 en fortjenestmedalje ledsaget af en takkeskrivelse med egenhændig underskrift af kejser Wilhelm 1. (1797-1888). I 1897 fik hun i anledning af kejser Wilhelm 1.'s 100 års fødselsdag en mønt af 
stål, der tildeltes ikke-kombattanter. På hendes 70 års fødselsdag i 1905 fik hun en personlig skrivelse fra prins Heinrich af Preussens gemalinde, der var formand for Røde Kors i Slesvig Holsten. I 1907 fik hun af overpræsidenten i Slesvig Detlev Theodor von Bülow Røde Korsmedaljen af 3. klasse. Dette var de officielle taksigelser for hendes indsats for syge mennesker. ${ }^{20}$

De mennesker, der i dag kan erindre fru Tutein, gør det på grund af hendes behandling af syge mennesker og den måde, hvorpå hun praktiserede dette. Fru Tutein behandlede Åbenrå-borgere; men også mennesker på gennemrejse har draget nytte af hendes evner. Da dyreholdet $\mathrm{i}$ tiden omkring århundredskiftet var stort, var det nærliggende, at hun også søgte at helbrede dyr, hvilket der da også er adskillige beretninger om.

Fru Tutein blev i folkemunde kaldt Mutter Tutein eller det mere værdiladede Madame Tutein. Hun bliver beskrevet som en lille sirlig dame, der i folks erindring næsten altid gik i sort og havde en kapothat på, når hun bevægede sig udendørs.

Det vides ikke, hvornår fru Tutein begyndte sin aktivitet som sygdomshelbreder; men formentlig er hun først begyndt herpå omkring 1880. Hun boede hele sin tid i Åbenrå i sit barndomshjem på Nybro nr. 8. Fru Tuteins hus blev nedrevet i 1970'erne, da det måtte vige for en moderne forretningsbygning. Hun boede på 1 . sal, og man kom derop ad en smal, mørk trappe. Man kom direkte ind i dagligstuen, der vendte ud mod Nybro og havde to små vinduer. Den var indrettet, som det var almindeligt dengang i gode borgerhjem. De fleste kan huske, at der stod en stor sofa i stuen.

Man kunne direkte og spontant henvende sig til fru Tutein, idet man blot gik op til hende, og hvis hun var hjemme, tog hun sig også af vedkommende. Det fortælles, at børn ofte uden forældrenes ledsagelse blev sendt til fru Tutein, hvilket vidner om den tillid, hun nød blandt både børn og forældre.

Når en patient kom til fru Tutein, spurgte hun om, hvilke symptomer vedkommende havde, og hvor længe disse havde stået på. Såfremt hun mente, at kunne gøre noget ved det, kunne det videre forløb være, at hun »læste« over lidelsen. Denne seance skal altid være blevet afsluttet med ordene $" I m$ Namen des Vaters, des Sohnes und des Heiligen Geistes«. Der foreligger ingen beretninger om, at man under disse seancer har følt sig mærkeligt tilpas, eller at nogen skulle være blevet dårlig. Ingen har bemærket, at fru Tutein skal have været $i$ trance eller lignende. Ofte efterfulgtes denne seance med en behandling, der kunne 
fortsættes hjemme. Man kunne straks efter behandlingen gå hjem, eller børnene kunne fortsætte med at lege. Alle, der henvendte sig, skal have fået godt råd af fru Tutein. Man har indtryk af, at hun har kendt sine begrænsninger, idet det ikke helt sjældent berettes, at hun har henvist til byens læger, når hun mente ikke at kunne gøre noget ved det, patienten henvendte sig med. ${ }^{21}$

Fru Tutein har, så vidt vides, aldrig taget mod kontant betaling, men nok med tak modtaget visse naturalier, som hun bl.a. kunne benytte til at lave sine sårplastre med. Hun har med glæde modtaget f.eks. honning, æbler, kartofler og mønje. Der foreligger ingen beretninger om, at fru Tutein har ordineret indvortes medicin. Hun har beskæftiget sig med hudlidelser eller hudmanifestationer af interne sygdomme. De hyppigste lidelser har nok været eksemer, skinnebenssår, rosen, hudinfektioner, brandsår og helvedesild. Ydermere har hun taget sig af forstuvninger og mindre sår, som hun mente at kunne behandle. Som nævnt ovenfor har hun ikke taget mod kontant betaling, så rig er hun ikke blevet. Af de endnu eksisterende skattelister fremgår det, at hun faktisk ikke har betalt skat.

Det er i dag vanskeligt at vurdere hvilke befolkningsgrupper, der især har henvendt sig til fru Tutein. Indtrykket er, at både dansk- og tysksindede borgere i lige høj grad benyttede sig af hendes evner. Socialt set har det nok især været håndværkere og det lavere borgerskab.

Det vides med sikkerhed, at fru Tutein har prøvet sine evner på dyr. Det fortælles således, at hun på markedsdage havde dyr opstaldet i en lille gård, hun havde bag sin ejendom på Nybro. Landmændene kunne således ved markedets afslutning hente deres dyr, der i mellemtiden var blevet behandlet. Tidligere boede der en del landmænd i Nygade. En af disse havde en hest, der havde făet rosen i det ene ben. Efter forgæves at have behandlet hesten på traditionel vis henvendte han sig til fru Tutein. I dette tilfælde vides det, at hun har opsøgt det syge dyr, men betingelsen var, at kun hun og bonden var på ejendommen den aften, hun skulle tilse dyret. Man ved derfor ikke, hvad der konkret er sket, men hesten blev rask.

Vedrørende fru Tuteins behandlingsprincipper af mennesker ved vi derimod mere. Det er dog nærliggende at tro, at der ikke har været stor forskel på hendes veterinære og humane behandlingsmetoder. Før en mere detaljeret beskrivelse af fru Tuteins behandlingsprincipper er det rimeligt at nævne nogle små historier, der beretter om hendes evner og held til at behandle syge mennesker.

Det fortælles således, at en ung mand, der af doktor Wiemer på 
Åbenrå sygehus var blevet opereret for tuberkulose $\mathrm{i}$ det ene knæ, havde fået betændelse $i$ såret. Trods omhyggelig pasning af sygehusets diakonisser var han ikke blevet rask. Han blev derfor, efter i mange måneder at have ligget på sygehuset, sendt hjem til sine forældre med sin infektion i benet. Den unge mand blev imidlertid mere afkræftet og syg, og i sin fortvivlelse opsøgte hans moder fru Tutein. Hun lovede at ville hjælpe så godt, hun kunne. Som behandling foreslog hun, at moderen rensede såret med sæbeskum, tørrede såret og derpå anlagde fru Tuteins sårplaster. Efter få ugers forløb skal den unge mand være blevet rask - $\mathrm{i} ø v$ rigt til dr. Wiemers store forundring. Dr. Wiemer var nabo til den unge mands familie i Fiskergade.

Et andet tilfælde drejede sig om en lille pige, der havde fået rosen i ansigtet. Efter forgæves at være blevet behandlet på Åbenrå sygehus, blev hun overflyttet til Universitetssygehuset i Kiel. Her lå hun i månedsvis og blev mere og mere syg. Familien besøgte ofte barnet; men forståeligt nok led hun meget af hjemve. Da hun ikke fik det bedre, besluttede forældrene at tage barnet med hjem til jul, for at de kunne fejre denne højtid sammen. Efter at være kommet hjem til Åbenrå opsøgte faderen fru Tutein, der kendte pigen godt. Fru Tutein skal have behandlet barnet med sit sårplaster, og i løbet af ganske kort tid fik hun det så meget bedre, at hun ikke behøvede at vende tilbage til sygehuset $\mathrm{i}$ Kiel.

Der findes mange beretninger om, at fru Tutein har helbredt folk med bylder på halsen, i armhuler og i lyskeregionen. Et gennemgående træk ved samtlige beretninger er, at hun ikke har ordineret indvortes medicin. Den indvortes behandling var imidlertid meget populær på hendes tid. Der blev således givet teer, udkog, udtræk, supper og tørrede komponenter fra blade, rødder og døde dyr. Meget yndet var det på apoteket at købe Kronessens og Hoffmansdråber, disse midler kan stadig købes på apotekerne.

Samstemmende beretninger er meddelt om fru Tuteins behandling af visse lidelser, der mere detaljeret vil blive omtalt. Ligtorne har utvivlsomt været meget udbredt, nok mere end de er i dag. En god og effektiv metode var at blande saften fra løg med salt. Efter i nogle dage at have påsmurt denne mikstur skal ligtornene have løsnet sig. Det fortælles dog også, at der enkelte gange er blevet "læst « over ligtornene, hvorpå man hjemme skulle fortsætte med at påsmøre den saltholdige løgsaft.

Bylder har ligeledes været meget udbredt. Denne tilstand har altid været præget af ubehag og smerte. Nogen smertelindring kunne man 
opnå ved at lægge grødomslag på bylden, især skal havregrød blandet med kamillete have været godt. Det fortælles dog, at også sårplastre med held har været anvendt mod bylder. Mindre sår og hudafskrabninger kunne behandles ved at påsmøre svinefedt i et tyndt lag. Brandsår, forstuvninger, rosen, »Gürtelrose« og ringorm kunne med held behandles med fru Tuteins sårplaster.

I et lille håndskrevet hæfte fyldt med gode madopskrifter fandt jeg ved et tilfælde en opskrift, hvor der stod, at den stammede fra "Mutter Tutein, Apenrade«. Det viste sig at salven var god mod »Bartflechte«, et begreb, der måske kan dække over skægpest eller psoriasis. Opskriften var dateret 1899 , og er blevet brugt på Gråstenegnen. Midlet var sammensat på følgende måde:

\section{for 30 øre Lilienoel \\ 30 øre Jungfernwachs \\ 30 øre Venetianischen Terpentin.}

Dette skulle tilsmages og derpå smøres godt ind i huden. Efter et døgn skulle det vaskes af med grøn sæbe. Opskriften er interessant alene derved, at mængdeangivelsen sker i den danske møntsort øre.

Det fortælles, at lægerne på Gråstenkanten i en årrække tjente helt godt ved at ordinere ovenstående til deres patienter, indtil apotekeren i Gråsten kom til at fortælle, at det var håndkøbsmedicin, og man kunne spare receptgebyret. Forholdet mellem apotekeren og lægerne i Gråsten skal efter den tid være blevet væsentlig mere afkølet.

Urenheder i huden, »bumser «, er søgt behandlet ved afvaskning af huden med vand, hvori der $\mathrm{i}$ mindst $1 / 2$ time havde ligget frisk piletræsbark. Vorter har formentlig været en hyppig henvendelsesårsag. Der findes i nutidig lægevidenskabelig litteratur adskillige behandlingsforslag. Dette tyder på, at intet er særlig effektivt. Det skal dog anføres, at vorter har en betydelig tilbøjelighed til spontan helbredelse. Fru Tuteins behandling bestod $i$, at hun "læste« over vorten, det vil sige, at hun mumlede noget uforståeligt, der sluttede med ordene: "Rose steche nicht, Feuer brenne nicht « og så det tidligere nævnte: ॥Im Namen des Vaters, des Sohnes und des Heiligen Geistes«. Medens hun "læste« over vorten, bandt hun med en uldtråd tre knuder under og tre knuder over vorten. Når hun var færdig hermed, pustede hun på den. Derefter skulle vorten være væk ved næste fuldmåne. I samtlige beretninger har jeg hørt, at dette også var tilfældet.

Af det beskrevne har man bemærket, at de fleste hudlidelser på en 


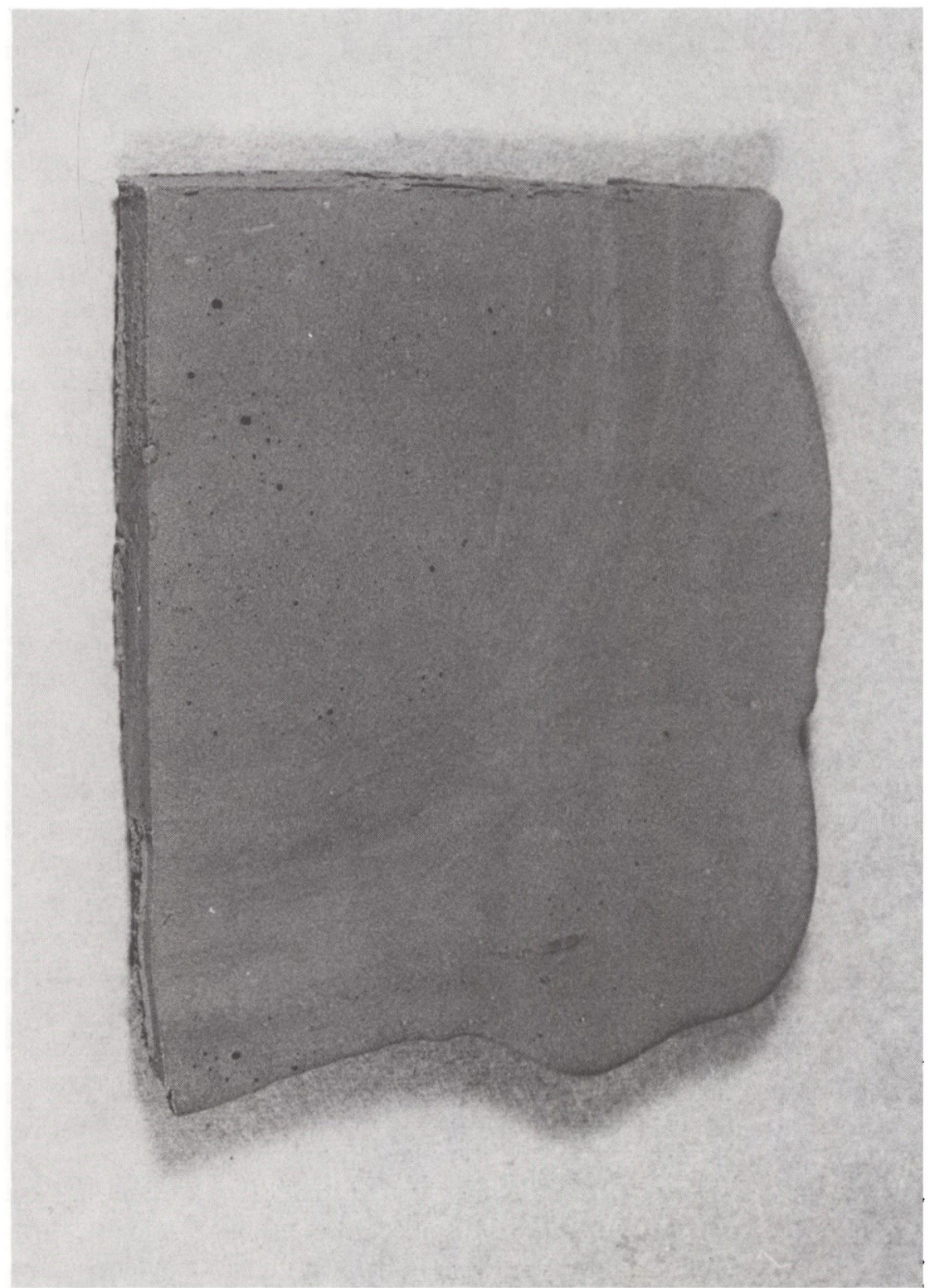

Säplaster af den type, fru Tutein brugte. Det er $10 \times 10 \mathrm{~cm}$. stort og har en tykkelse pd $5 \mathrm{~mm}$. Det er porest, og farven er okkerred. Ved opvarmning over vanddamp kunne sårplastret formes efter den struktur, det skulle lagges pd. Oven på sårplastret kunne man lagge en forbinding, der holdt det pd̊ plads. 
eller anden måde kunne behandles med »fru Tuteins sårplaster«. Dette sårplaster havde stor berømmelse både i og uden for Åbenrå. Plastret kunne, medens fru Tuein var yngre, fås hos hende selv, idet hun har lavet det af de naturalier, hun fik af sine patienter. På sine ældre dage havde hun ikke kræfter til selv at fremstille sårplastret, derfor overtog apotekerne i Åbenrå produktionen og salget. Det kunne købes uden recept, og endnu i dag er det en håndkøbsvare på Åbenrå Løveapotek.

Sårplastret, således som fru Tutein lavede det, bestod af en blanding af bivoks, tælle, mønje og johannisolie, der blev blandet sammen $i$ et bestemt forhold, for derefter at blive opvarmet. Herefter var det meget vigtigt, at blandingen hurtigt blev afkølet, idet dette var en forudsætning for, at sårplastret fik sin rette konsistens. Denne procedure nødvendiggjorde store mængder koldt vand, og det fortælles, at fru Tutein derfor lavede sit sårplaster ved Mølleåen - i fuldmåne!

Det apoteksfremstillede plaster bestod af:

$\begin{array}{lll}\text { emplastrum plumbi } & \text { gram } 360 \\ \text { cera flava } & \text { gram } 20 \\ \text { terebenthinae lacricis } & \text { gram } 20 \\ \text { olibanus sigte } 0,2 \mathrm{~mm} & \text { gram } 20 \\ \text { color miniralis rubor } & \text { gram } 30\end{array}$

De fire førstnæunte bestanddele blev smeltet sammen over vandbad og udreves med det femte, hvorpå det hele støbtes i en pergamentform og blev afkølet. Herefter blev det udskåret i stykker på ca. 50 gram. Ved brug skulle plastret under opvarmning blødgøres og lægges på det syge sted. Plastret var et rødt, porøst stof uden lugt. Umiddelbart kunne man tro, at dette var et af fru Tutein selvkomponeret behandlingsmiddel. Det var imidlertid ikke tilfældet. I Hagers "Handbuch der Pharmazeutischen Praxis«, bd. 1, Berlin 1919 står opskriften i næsten identisk form som beskrevet ovenfor. Der er god grund til at antage, at lignende plastre har været brugt i England og Frankrig. I Pharmacopea Danica fra 1840 omtales ligeledes et plaster, der på mange måder ligner det, fru Tutein har brugt. De mennesker, der efter fru Tuteins død købte plastret på apoteket påstod, at det havde en anden rød farve end tidligere, og i hvert fald havde det slet ikke samme gode virkning som for. ${ }^{22}$

Efter fru Tuteins død har flere forsøgt sig med at fortsætte hendes aktiviteter som sygdomshelbreder. Ifølge gammel tradition skulle denne evne gå over til et familiemedlem af det modsatte køn. En nevø 
prøvede også en overgang at fortsætte arbejdet, men uden held. Tiden var blevet en anden, og interessen for denne form for helbredelse blevet mindre.

Fru Tuteins sidste år var præget af sygdom og tiltagende svagelighed. Hun fik en god og kærlig pleje hos sin broder snedkermester Andreas Petersen, hos hvem hun også døde den 28. maj 1927 »en skøn forårsmorgen klokken kvart i seks«.

Efter hendes død har der, så vidt jeg har kunnet registrere, kun været skrevet en enkelt gang om hende, nemlig i Dannevirke/Hejmdal den 27. februar 1971. I denne avisartikel gengives en del af et indtalt bånd om fru Tutein, der findes i Historiske Samlinger for Sønderjylland.

\section{KILDER, LITTERATURHENVISNINGER OG NOTER}

1. Poul A. Pedersen: Selvbehandling inden henvendelse til praktiserende læge. Ugeskrift for Lager nr. 32, 1976, s. 1955-1961.

2. Vilhelm Ingerslev: Danmarks Læger og Lægevæsen fra de ældste Tider indtil år 1800. Bd. 1, s. 319. København 1873.

3. Medicinal und Apotheker-Ordnung für die Königl. Reiche und Lande vom 4.12.1672.

4. Thomas Achelis: Die Ärzte im Herzogthum Schleswig bis zum Jahre 1804. Kiel 1966.

5. Patent wegen Errichtung eines Sanitäts-Collegiums für die Herzogthümer Schleswig und Holstein, Herrschaft Pinneberg Grafschaft Rantzau und Stadt Altona vom 25.5.1804.

6. Thomas Achelis: Haderslev i gamle Dage 1627-1800, Haderslev 1929.

7. Hugo Weller: Aus dem Archive des Sonderburger Physicates. I Heimat Blätter für den Kreis Sonderburg, nr. 12 nov. 1921.

8. Max Rasch: Von Barbieren, Chirurgen und den ersten gelehrten Medizinern in der Stadt Apenrade. I Die Heimat 1951.

9. Johannes Brix: Lagevirke i Sønderjylland før 1864, Herning 1980.

10. Ved lov nr. 561 af 5.4. 1875 var der sket en nyopdeling af Ảbenrå fysikatsdistrikt, således at det kom til at falde sammen med Ábenrå kreds. Foruden læger i Åbenrå praktiserede der også læger i Gråsten.

11. Uden at ville udtale mig om lægernes økonomiske forhold på fru Tuteins tid, er det dog interessant at se på de ejendomme, som de beboede og drev deres praksis fra. De var alle af anselig størrelse. Således boede Dr. Wiemer Fiskergade 7, det nuværende Sct. Ansgar. Dr. Dibbern byggede det anselige hus Skibbrogade 6 i 1891, Butzbach byggede huset Møllegade 5, og dr. Huss opførte huset Ramsherred 8, hvor der stadig er lægepraksis. At det ikke gik alle læger lige godt, kan man se deraf, at dr. Wildfang, der i 1885 havde nedsat sig i byen, byggede huset Sondergade 7 i 1890, men p.gr. af det alt for store byggeri forlod han Åbenrå i 1892 efterladende en betragtelig gæld. 
12. I 1878 kom de første diakonisser til Åbenrå som menighedsplejersker. Dette var foranlediget af den unge nyudnævnte diakon Theodor Christian Heinrich Kaftan (1847-1932). Han blev senere generalsuperintendant for Slesvig.

13. Lise Julie Tutein: Slægten Tutein. Privat tryk.

14. Hans Schlaikier: Apenrader Schiffahrts Chronik, Åbenrå 1929.

15. F. Holm-Petersen: Under sejl i fjernøstlige farvande, Norderstedt 1975.

.16. Gerd Stolz: Das Militärsanitätswesen der Schleswig-Holsteinischen Armee. I Die Heimat, nr. 2, februar 1977 og nr. 6, juni 1977.

17. Dr. Kimmle: Die Kriegschirurgen und Feldärzte Preussens und anderer deutscher Staaten, Kiel 1904.

18. Statut des Vaterländischen Frauenvereins zu Berlin vom 1.5. 1867, revidiert am 24.5. 1869.

19. Vaterländischer Frauenverein. Foreningsarkiver Ábenrå Amt og by nr. 180, kasse 95, 96 og 97. Landsarkivet i Åbenrå.

20. Nekrolog i Apenrader Tageblatt den 28.5. 1927. I en skrivelse fra landsråden dateret den 20.11. 1906 er hendes aktiviteter også ridset op. Skrivelsen findes i Åbenrå landrådsarkiv, B7. Landsarkivet i Åbenrå.

21. Med gennemgang af fysikatsarkiverne har man ikke kunnet finde noget, der kunne tyde på, at der på noget tidspunkt har været rejst tiltale mod hende for kvaksalveri el.lign.

22. I Farmakopeerne benævnes et plaster, der ligner fru Tuteins, som Emplastrum defensivum rubrum. Det skal dog nævnes, at der ud over det røde sårplaster fandtes et grønt, nemlig Emplastrum defensivum viride. Sammensætningen af dette er anført i Danske Farmakopeer indtil 1925 af H. R. Zeuthen. 
